DOI: doi.org/10.21009/IJLECR.051.10

Received: 20 January 2019

Revised: 1 February 2019

Accepted: 12 March 2019

Published: 30 June 2019

\title{
THE ROLE OF PERSONALITY TRAITS IN ARABIC LISTENING LEARNING
}

\author{
Raden Ahmad Barnabas ${ }^{1, a)}$, Tutik Cholisotin ${ }^{1, b)}$, Nadia Fitriani ${ }^{1, c)}$ \\ Arabic Education Program Study State University Jakarta, Indonesia ${ }^{1)}$ \\ barnabas@unj.ac.id ${ }^{1)}$,_tutikcholisotin@gmail.com ${ }^{\text {b) }}$, nadiafitrian0101@ gmail.com.com ${ }^{\text {c) }}$
}

\begin{abstract}
The purpose of this study was to find out Students' listening ability in Arabic learning that has differences personalities. This study used a quantitative approach with experimental methods. It used a treatment pattern $2 \times 2$ design. The process of collecting data used questionnaires, tests, observations, and documentation. The data analysis technique is a 2 -way variant analysis. The results showed that there are differences in each treatment group, there are differences in Arabic listening ability between students who have extrovert and introvert personality. On the results of analysis of variance at a significance level of 0.05 obtained F-count $=24$ and F-table $(0.05 ; 1: 40)=$ 4.085. The results of the calculation of two-way ANOVA are obtained by the results of $F$ count $>\mathrm{F}$ table, the test results are significant or $\mathrm{H}_{0}$ is rejected. This means that there are differences in the Arabic listening ability between students who have an extroverted personality and introverted personality.
\end{abstract}

Keywords: Arabic, Listening, Extrovert, Introvert

Personality has a significant influence on students' achievement in Arabic learning process. There are two personality problems that must be considered by lecturers when designing Arabic listening learning activity in the classroom, namely (1) students who have introverted personalities have difficulty absorbing material because they tend to be more silent; while (2) extrovert's personality has an in-depth understanding of the material so that when the learning strategy used does not meet the needs of the student, it causes boredom during learning. So, personality has a considerable influence on the use of learning strategies in improving the Arabic listening ability. It can be seen from Liyanage \& Bartlett (2013) studied that shown Language Learning Strategy (LLS) preferences of learners of English as a Second Language (ESL) and their personality types are positioned within the contention that the two are generally related. However, they also provide the basis for the important caution that the association between personality types and LLS is quite volatile. We have found that it is variation rather than unwavering stability that features in how personality traits apply as predictive of ESL learners' specific LLS preferences. Such prediction is specified even further by the particular contexts of ESL learning where the LLS are applied, for example for listening or speaking and whether this occurs inside or outside a classroom.

The results of the preliminary research found that some of the problems of Arabic listening learning that are related to student personality are: a) students are not passionate and do not have the enthusiasm to learn to listen to both at class and doing exercises at home; b) the level of student 
attention to the desire to complete the listening task like as studied by Bayona \& Castañeda (2017); c) lack of stimulus to focus on listening material; d) students have a sense of indifference to the usefulness of listening skills; e) students are ashamed to ask questions and lack of willingness to discuss especially for students with closed personalities; f) students who have the ability to be less able to share knowledge; and g) there are students who are open but not right in acting

Therefore, there are two personality problems that must be considered by lecturers when designing listening learning activities in the classroom, namely (1) students who have introverted personalities have difficulties in absorbing material because it tends to be more silent; while (2) extrovert's personality has an in-depth understanding of the material, so that when the learning strategy used does not meet the needs of students it causes boredom during learning. So, personality has a considerable influence on the use of learning strategies in improving the ability of Arabic listening.

From the findings of the student personality problems, lecturers as facilitators of learning should have information about the different types of students in the class so they can provide different treatments (Crozie, 2001). This means that the lecturer must understand the type of personality of the student, whether introverted or extroverted when the learning process is implemented, it can provide clear and easy learning instructions for all students. This can have an impact on achieving the stated listening learning objectives. So, information about student personality is very important to be known by the lecturers so that the teaching and learning process can run successfully. It can be seen from the results of previous studies.

One of the studies conducted by Alavinia and Sameei (2012) about the potential of the extrovert and introverted personality of students in listening learning, the results showed that there was a significant relationship between listening ability and personality characteristics, namely extroversion vs. introversion. When students have an introverted personality, the better their performance in listening. However, as revealed by the findings, there was no significant interaction between sex and introversion/extroversion or between introversion/extroversion and the age of students on listening skills.

From the explanation of the above problems, it is known that personality has a relationship that cannot be separated from learning strategies. The application of appropriate learning strategies is the responsibility of the lecturer. This means that the problem of learning strategies comes from the lecturer. therefore, the lecturer must properly analyze the need for Arabic listening learning. The results of the identification of the initial problem are known that the listening process in the Arabic Language Education Study Program State University Jakarta uses a single and uniform teaching strategy to instruct heterogeneous classes of diverse students with different talents and personalities. In addition, other problems are (1) lack of attention to individual preferences; (2) difficulties in applying learning strategies to the diversity of student personalities.

Thus, this study aims to get students' Arabic listening ability with the differences in personality. Thus, research problem; how are there differences of Arabic listening ability between groups of students who have extroverted personalities and groups of students who have introverted personalities?

\section{METHOD}

This study used the experimental method using factorial group design $2 \times 2$. It is quantitative research. It is one type of research that tests hypotheses to determine causal relationships (Gay, Geoffrey, \& Airasian, 2009). In quantitative research, the researcher identifies a research problem based on trends in the field. It can be answered best by a study in which the researcher seeks to establish the overall tendency of responses from individuals and how this tendency varies among people (Creswell, 2012). The sampling technique is a multistage cluster random sampling 
technique. Sample of research was taken by 22 students. Each group has 11 students for an introvert and extrovert personality. The process of collecting data used; 1) documentation; 2) test and 3) observation. The data analysis used 2 ways variance analysis technique with the significance level $\alpha$ $=0.05$ and $\alpha=0.01$. If the results of data analysis found an interaction, the researcher continues to analyze the data with the Dunnet t-Test. The normality test uses the Liliefors test, while the homogeneity test uses the Bartlett test at the level of confidence $\alpha=0.05$.

\section{RESULTS AND DISCUSSION}

The results of data analysis in Arabic listening teaching that have an extroverted personality indicate the highest score is 90 and the lowest score is 58 with an average value of 84.18. While the median score is 84.5 , mode score is 84 , the variant is 35.77 , and the standard deviation is 2.8 . From the results of the calculation, the following is an explanation of the score of the Arabic listening ability arranged in the frequency distribution table as follows

Table 1. Distribution of Frequency for Extrovert Group

\begin{tabular}{|l|c|c|c|c|c|c|}
\hline \multirow{2}{*}{ No } & \multirow{2}{*}{ Interval } & \multicolumn{2}{|c|}{ Limit } & \multicolumn{3}{c|}{ Frequency } \\
\cline { 3 - 7 } & & Below & Up & Absolut & Cumulative & Relatif \\
\hline 1 & $70-75$ & 69,5 & 75,5 & 3 & 3 & 13,64 \\
\hline 2 & $76-81$ & 75,5 & 81,5 & 1 & 4 & 4,54 \\
\hline 3 & $82-87$ & 81,5 & 87,5 & 13 & 17 & 59 \\
\hline 4 & $88-93$ & 87,5 & 93,5 & 4 & 21 & 18,18 \\
\hline 5 & $94-99$ & 93,5 & 99,5 & 1 & 22 & 4,54 \\
\hline \multicolumn{3}{|c|}{ Total } & 22 & & $100 \%$ \\
\hline
\end{tabular}

From the frequency distribution table 1 in the extrovert group, it is known that there are $18.28 \%$ of student groups that have scored above the average score, and $22.72 \%$ of students are below the average. While the percentage of students in the average score range is $59 \%$. From the table data presented, it is visually illustrated on the histogram chart below;

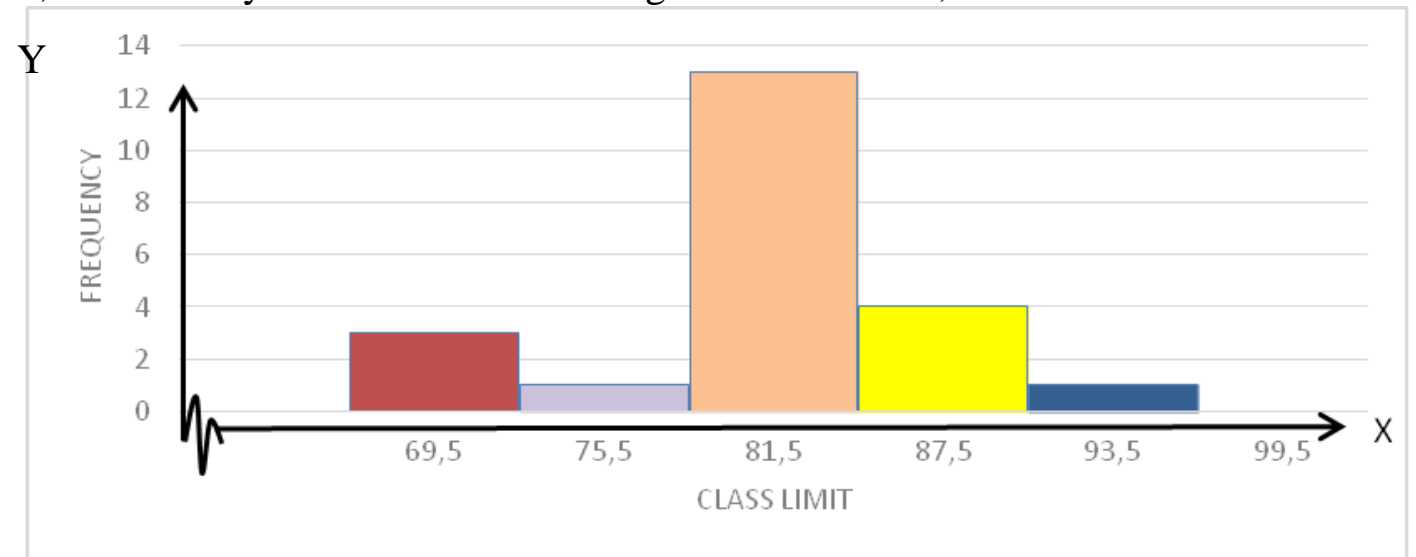

Graph 1. Histogram of Extrovert Group Distribution Frequency

While the results of Arabic listening that have an introverted personality indicate the highest score is 82 and the lowest score is 58 with an average score of 70.95 . While the median score obtained 69.5, mode score 69, variant 59.38, and standard deviation of 4.55. From the results of the calculation, the following is an explanation of the score of the Arabic listening ability arranged in the frequency distribution table as follows 
Table 2. Distribution of Frequency for Extrovert Group

\begin{tabular}{|l|c|c|c|c|c|c|}
\hline \multirow{2}{*}{ No } & \multirow{2}{*}{ Interval } & \multicolumn{2}{|c|}{ Limit } & \multicolumn{3}{c|}{ Frequency } \\
\cline { 3 - 7 } & & Below & Up & Absolut & Cumulative & Relatif \\
\hline 1 & $58-63$ & 57,5 & 63,5 & 4 & 4 & 18,18 \\
\hline 2 & $64-69$ & 63,5 & 69,5 & 7 & 11 & 31,82 \\
\hline 3 & $70-75$ & 69,5 & 75,5 & 4 & 15 & 18,18 \\
\hline 4 & $76-81$ & 75,5 & 81,5 & 5 & 20 & 22,72 \\
\hline 5 & $82-87$ & 81,5 & 87,5 & 2 & 22 & 9 \\
\hline \multicolumn{3}{|c}{ Total } & 22 & & $100 \%$ \\
\hline
\end{tabular}

From the frequency distribution table 2 in the introvert group, it is known that there are $50 \%$ of student groups that have scored above the average score, and 31,82\% of students are below the average. While the percentage of students in the average score range is $18,18 \%$. From the table data presented, it is visually illustrated on the histogram chart below;

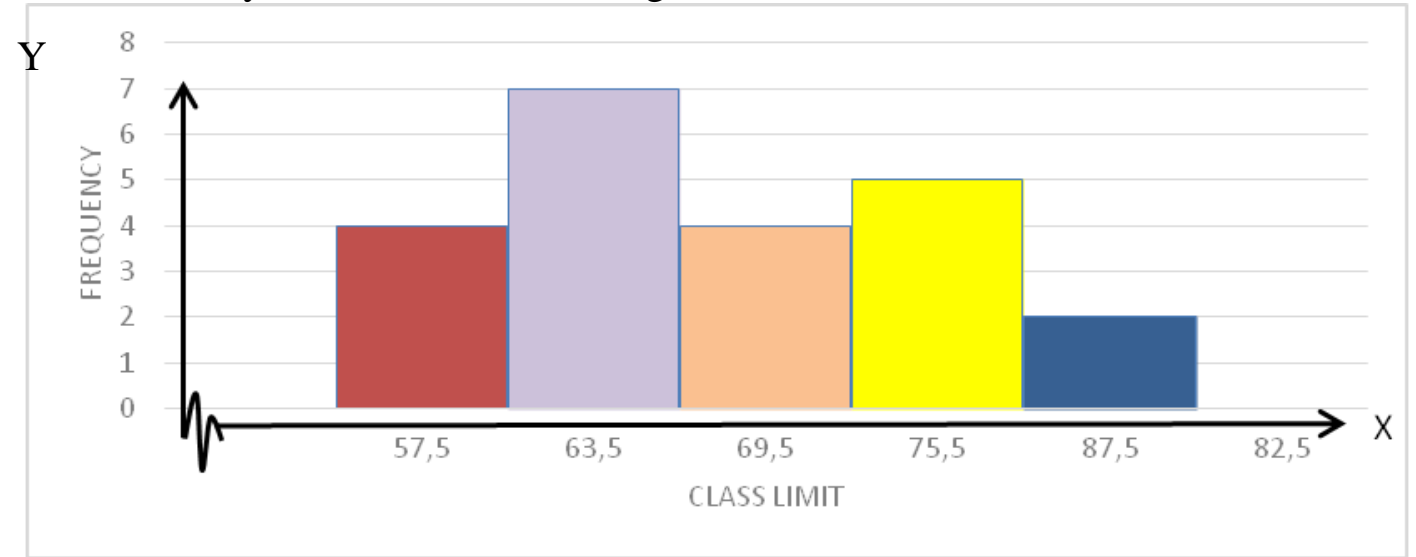

Graph 2. Histogram of Introvert Group Distribution Frequency

Based on the results of analysis of variance at a significance level of 0.05 obtained F-count $=24$ and F-table $(0.05 ; 1: 40)=4.085$. The results of the calculation of two-way ANOVA are obtained by the results of Fcount> Ftable, the test results are significant or $\mathrm{H} 0$ is rejected. This means that there are differences in the Arabic listening ability between students who have an extroverted personality and introverted personality. It can be concluded that extroverted personality $\left(\mathrm{Y}_{-}^{-} \mathrm{A} 1=84.18\right)$ is better than introverted personality $\left(\mathrm{Y}_{-}^{-} \mathrm{A} 2=70.95\right)$. From the results of different average score, it is clear that there are differences in student abilities seen from the type o[f personality possessed by each student. This can be seen also from the large percentage of the influence of the free variable on the dependent variable. Personality types can explain $35.82 \%$ of the variation in the ability to listen to Arabic. So it can be concluded that the research hypothesis which states that the overall score of the Arabic listening ability that have extroverted personalities is better than the group of students who have an introverted personality can be accepted.

Students who have an extrovert personality have the lowest score of 70 and the highest score is 94. The test scores for listening to the most Arabic are obtained by students as many as 84 people, test scores of 84 obtained by 4 people, test scores of 82.85 and 89 obtained by 2 people, and the test scores were 72.74,80.90, and 92 were obtained by 1 person. Test scores on students who have extroverted personality have been dominated in the range of 80 to 94 as many as 18 students know $81.8 \%$ and students who get test scores below the score of 80 are 4 students or $18.2 \%$.

Students who have an introverted personality have the lowest score of 58 and the highest score of 82 is 2 students. The scores of the most Arabic listening tests obtained by students were 69 
as many as 4 people, the test scores were 79 obtained by 3 people, the test scores were 60.70 , and 80 were obtained by 2 people, and the test scores were $59.65,67,68,72$, and 75 obtained by 1 person. Test scores on students who have introverted personality are in the range of 70 to 82 as many as 11 students or $70 \%$ and students who get test scores below 70 are 11 students or $50 \%$. The success of this research has also been proven by previous researchers. But in this study, it has found something different from previous research. In this study, it has been supported by the management concept of self-regulation of students so that they have no difficulty when receiving treatment during the learning process of Arabic listening. Because the listening process requires intensive practice. As in research (الحوامدة \&الخوالدة, 2016), it has been researching to improve the ability of Arabic teachers through the practice of understanding strategies. This is the same as what has been done (Rahimi, Thursday, \& Normeza, 2013). So, the listening process is made easier by students when they want to practice continuously and regularly.

However, the practice becomes worthless when students lack enthusiasm for learning. This means that students have a personality is not managed well. So that it has less impact on listening ability. In the research of Ghaemi and Sabokrouh (2015) or research from (Alavinia \& Mollahossein, 2012) about personality differences in the application of listening learning strategies. Language learning varies depending on individual characteristics and variations in language learning outcomes associated with student characteristics. If it is understood as a whole that influences the success or achievement of students not only come from the students themselves or the use of learning strategies but learning resources become an important part that cannot be separated. In this study, experimental activities also used teaching materials that were not easy. This means that the teaching material provided is adjusted to the level and given a higher level of material and authentic. So that it can stimulate the mindset of students to become wider. As has been done in the Hamada study (2011).

\section{CONCLUSION}

Overall the average score of Arabic listening ability with an extrovert personality of 84.18 is better than students who have an introverted personality. Therefore, the success of the Arabic listening learning process is influenced by the students themselves. Factors that originate from students must be considered and used as material for analysis. Because the main factor that most influences the increase in the Arabic listening ability is themselves. So, lecturers should provide opportunities for students to develop themselves during the teaching and learning process.

\section{REFERENCE}

Alavinia, P., and Sameei, A. (2012). Potential Bonds between Extroversion/Introversion and Iranian EFL Learners' Listening Comprehension Ability. English Language Teaching, 5(5), 19. https://doi.org/10.5539/elt.v5n5p19

Bayona, J. A., and Castañeda, D. I. (2017). Influence of personality and motivation on case method teaching. The International Journal of Management Education, 15(3), 409-428. https://doi.org/10.1016/J.IJME.2017.07.002

Creswell, J. W. (2012). Educational Research: Planning, Conducting and Evaluating Quantitative and Qualitative Research. London \& New York: Pearson Education.

Crozie, R. (2001). Individual Learners: Personality Differences in Education. London: Taylor \& Francis e-Library.

Gay, L. ., Geoffrey, E. M., and Airasian, P. (2009). Educational Research Competencies for Analysis and Applications Ninth edition. United State of America: Pearson.

Ghaemi, F., and Sabokrouh, F. (2015). The Relationship between Personality Traits and Metacognitive Listening Strategies among Iranian EFL Learners, ELT. Voices- International 
Journal for Teachers of English, 5(2).

Hamada, Y. (2011). Improvement of Listening Comprehension Skills through Shadowing with Difficult Materials. Spring, 8(1), 139-162.

Liyanage, I., and Bartlett, B. (2013). Personality types and languages learning strategies: Chameleons changing colours. The system, 41(3), 598-608. https://doi.org/10.1016/J.SYSTEM.2013.07.011

Rahimi, N. M., Kamis, M. S., and Normeza, W. (2013). The misconception of Arabic language listening skills among teachers. Social Sciences (Pakistan), 8(4), 347-350. https://doi.org/10.3923/SSCIENCE.2013.290.294

لممارساتهم الأردن في العليا الأساسية المرحلة في العربية اللغة معلمي تقدير درجة .(2016) .ف .م ,الحوامدة \& ع ..ع .م رالخوالداة The Estimation Degree of Jordanians Arabic Language Teachers in Upper Basic Stages of Their Listening Comprehension Teaching Strategies Practices. IUG Journal of Educational and Psychological Studies, 24(1), 74-90. https://doi.org/10.12816/0024410 